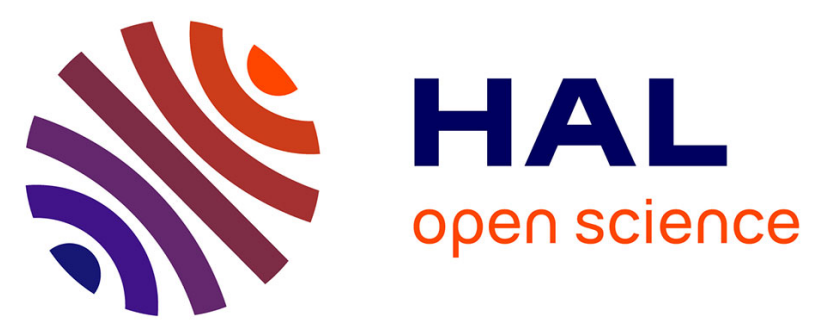

\title{
Anaerobic co-digestion of food waste and FOG with sewage sludge - realising its potential in Ireland
}

Olumide Wesley Awe, Yaqian Zhao, Ange Nzihou, Doan Pham Minh, Nathalie Lyczko

\section{- To cite this version:}

Olumide Wesley Awe, Yaqian Zhao, Ange Nzihou, Doan Pham Minh, Nathalie Lyczko. Anaerobic codigestion of food waste and FOG with sewage sludge - realising its potential in Ireland. International Journal of Environmental Studies, 2018, 75 (3), p.496 - 517. 10.1080/00207233.2017.1380335 . hal01787775

\section{HAL Id: hal-01787775 \\ https://imt-mines-albi.hal.science/hal-01787775}

Submitted on 12 Oct 2018

HAL is a multi-disciplinary open access archive for the deposit and dissemination of scientific research documents, whether they are published or not. The documents may come from teaching and research institutions in France or abroad, or from public or private research centers.
L'archive ouverte pluridisciplinaire HAL, est destinée au dépôt et à la diffusion de documents scientifiques de niveau recherche, publiés ou non, émanant des établissements d'enseignement et de recherche français ou étrangers, des laboratoires publics ou privés. 


\title{
Anaerobic co-digestion of food waste and FOG with sewage sludge - realising its potential in Ireland
}

\author{
Olumide Wesley Awe ${ }^{\mathrm{a}}$, Yaqian Zhao ${ }^{\mathrm{a}}$, Ange Nzihou ${ }^{\mathrm{b}}$, Doan Pham Minh ${ }^{\mathrm{b}}$ and \\ Nathalie Lyczko ${ }^{b}$ \\ aSchool of Civil Engineering, Dooge Centre for Water Resources Research, University College Dublin, Dublin, \\ Ireland; b ${ }^{b}$ Mines Albi, CNRS UMR 5302, Centre RAPSODEE, Université de Toulouse, Albi, France
}

\begin{abstract}
The severe environmental pollution in many countries is caused by indiscriminate discharge of large quantities of food waste (FW), fat oil and grease (FOG) and sewage sludge (SS) to the environment. There are many possible treatment routes, but anaerobic digestion $(A D)$ is now well accepted for treating several kinds of organic wastes. But AD of FW alone presents some operational challenges because of substrates and variability. Anaerobic co-digestion of two or more substrates is better than single substrate digestion. This can use a plant's unused capacity, in line with the trend to renewable energy. Co-digestion technology, although well established in many European countries, is still in its infancy in Ireland. There are problems with different regulatory arrangements. They should be resolved. The paper reviews anaerobic co-digestion technology is reviewed, with special focus on possible application in Ireland.
\end{abstract}

Abbreviations: $A B P$, anaerobic by-products; $A D$, anaerobic digestion; AS, activated sludge; ASBR, anaerobic sequential batch reactor; BMW, biodegradable municipal solid waste; BMP, bio-methane potential; $\mathrm{BNR}$, biological nutrient removal; $\mathrm{BOD}$, biochemical oxygen demand; $\mathrm{CGY}$, crude glycerine; $\mathrm{CH}_{4^{\prime}}$ methane; $\mathrm{C} / \mathrm{N}$, carbon nitrogen ratio; $\mathrm{COD}$, chemical oxygen demand; $\mathrm{CO}_{2}$, carbon dioxide; $\mathrm{CSTR}$, continuous stirred tank reactor; DM, dissolved matter; DS, dissolved solids; FFA, free fatty acid; FOG, fat, oil and grease; FVW, fruit vegetable waste; FW, food waste; GHGs, greenhouse gases; GW, grease waste; HRT, hydraulic retention time; LCFAs, long chain fatty acids; MSW, municipal solid waste; $\mathrm{NH}_{4}^{+}-\mathrm{N}$, ammonium nitrogen; $\mathrm{NH}_{3}$, ammonia; OFMSW, organic fraction of municipal solid waste; OLR, organic loading rate; $\mathrm{PE}$, population equivalent; $\mathrm{PS}$, primary sludge; $\mathrm{SBR}$, sequencing batch reactor; SMP, specific methane potential; SRT, sludge retention time; $S$, sewage sludge; $T$, temperature; TPAD, two-phase anaerobic digestion; TS, total solids; TSS, total suspended solids; UASB, upflow anaerobic sludge blanket; VFA, volatile fatty acid; VS, volatile solids; VSS, volatile suspended solids; WAS, waste activated sludge; WWTPs, wastewater treatment plants

\section{KEYWORDS}

FW; sludge; codigestion; FOG; biogas; biodegradability 


\section{Introduction}

Anaerobic digestion (AD) has been applied for over a century at wastewater treatment plants (WWTP) for stabilizing excess organic sludge and for biogas production. Growing interest in using this technology for treating other organic solids (organic waste and energy crops) comes with stricter regulations on organic waste disposal as well as the need to find alternative sources of energy [1-4]. The urgent need for renewable energy generation and the need to divert biodegradable waste from landfill have pushed $\mathrm{AD}$ into the market for treatment of the organic fraction of municipal solid waste (OFMSW). Food waste (FW) is the most challenging biodegradable fraction of this because of its high moisture content and readily biodegradable nature [5-8].

Generally, mono-digestion of single substrate has problems which include the seasonal nature of agricultural waste and variability of food waste. Sewage sludge has low organic loads. Municipal organic waste contains improper materials and is high in metal content. Animal manure is known to contain a high nitrogen concentration. Wasted oil is high in lipids. There can be long chain fatty acid (LCFA) production and inhibitions of methanogenic bacterial communities [2,10,11]. Anaerobic co-digestion can solve most of these problems by co-digesting two or more organic waste streams for optimisation and increased biogas yield and kinetic performance. It is important to select the best co-substrate and blend ratio, to favour synergy, dilute harmful compounds, optimise methane production and maintain digestate quality $[2,8]$.

The key to successful anaerobic co-digestion is the substrate, especially its composition and the proportion of each substrate in the feed mixture. It is vital to obtain the best chemical composition in order to optimise the activity of the biomass in the anaerobic process such as carbon-nitrogen ratio, $\mathrm{pH}$, alkalinity, etc. [12,13]. It is also important to avoid the inhibition of different components like ammonia, volatile fatty acids (VFAs), intermediate products, optimised biogas production and final effluent in the dewatering process $[2,8]$. Nghiem et al. [14] argue that technical and economic constraints may limit full-scale SS co-digestion operations. There are confusing laws in relation to SS and co-digestion with other waste, especially FW, meat and animal product, etc. in WWTP. These all create a major non-technical limitation coupled with waste availability and the lack of knowledge about adequate co-digestion strategies or their impact on the overall operation of a WWTP $[3,11]$.

Ireland's major agro-industrial units such as wineries, breweries, distilleries, cheese factories, other food factories and livestock units produce wastes, with high organic load, that could be used for anaerobic digesters in functioning WWTPs that produce biogas in significant quantities. Thus, co-digestion could be an opportunity for the water industry in Ireland to increase its renewable energy generation, without any additional facility. Revenue can be generated through gate fees or service charges [16]. This could reduce the environmental footprint. At the same time, the application of co-digestion of FW with SS will help Ireland to meet the EU Landfill Directive [17], which requires the reduction of biodegradable waste in landfill to $35 \%$ by 2020, based on the 1995 levels. Further, co-digestion could contribute to the achievement of targets set by the Climate Change Act and the EU Renewable Energy Directive [18]. The Climate Change Act requires the reduction of carbon emissions by 34\% by 2020, based on the 1990 levels. The EU Renewable Energy Directive requires 16\% of Ireland's total energy to come from renewable sources by 2020 [18-22]. 
Several studies have examined the benefits of FW co-digestion with SS, but only a few have examined the constraints. Optimal operational conditions in terms of percentages of co-substrates cannot be univocally defined but should be investigated for each specific case [23-25]. As for the physical and biochemical processes in a co-digestion system, only some have been investigated; other questions require to be further studied. These include the effect of the temperature on the process performance; the need for pre-treatments; the effect of solid mixtures' moisture content; the feeding systems of the solid mixture; the definition of the optimal stirring of the solid mixture in the digester. Thus, this paper aims to review the current knowledge on co-digestion of FW and fat, oil and grease (FOG) with wastewater treatment sludge. The benefits and constraints of the co-digestion technology will then be discussed with special reference to prospects for the application in Ireland.

\section{Substrates for co-digestion}

Previous studies have investigated well the anaerobic co-digestion of SS with several kinds of other materials. These include: source-sorted OFMSW [3,26], confectionery waste [27], municipal solid waste [28], FW [29-32], fruit and vegetable waste [34], industrial waste $[4,35]$, grease trap sludge [36-39], meat processing waste [6,37], crude glycerol $[3,40]$, and sludges from pulp and paper industry and enzyme production $[13,41,42]$.

The gas yield varies with the amounts of carbohydrate, proteins and lipids that are present in the mixes. Lipids provide the highest biogas yield, but require longer retention time owing to their slow kinetic of biodegradability; whereas, carbohydrates and proteins show fast conversion rates but low biogas yield. Thus, in the co-digestion process protein-rich wastes can provide the buffering capacity and a wide range of nutrients, and wastes with high carbon content can balance the $\mathrm{C} / \mathrm{N}$ ratio for all substrates characterised by a low $\mathrm{C} / \mathrm{N}$ ratio, thereby decreasing the risk of ammonia inhibition [9]. To overcome this limitation, researchers have concentrated on co-digestion of FW with SS to augment nutrient imbalance $[1,2,4,12,31,34,41,43,44]$.

Different waste combinations are possible for the co-digestion with SS based on the availability of substrates through different seasons. It is desirable that variation in the characteristics of the waste be minimum to avoid disturbances in the reactor [45]. The next sections address composition and characteristics of FW and FOG before discussing their co-digestion with SS.

\section{FW and FOG}

Among the materials for anaerobic co-digestion, FW and FOG are commonly used because of their high organic carbon and protein content in FW, as well as high lipid content of FOG waste. It has been reported that more than 1.3 billion tonnes of FW are discarded every year, with about 120 million tonnes coming from Europe [46]. According to the Food and Agriculture Organisation of the United Nation [47], the food waste and losses amount to roughly US\$ 680 billion in developed countries and over US\$ 310 billion in developing countries. This also amounts to wasting of resources used in producing the loss and wasted food, which includes land, water, labour and capital, energy, and the unnecessary production and emission of GHGs, thereby contributing to global warming and climate change [7]. According to EPA's 'Stop Food Waste' program, Ireland generates over 1 million tonnes of 
food waste annually (from the MSW) and this includes; households, commercial firms and food producers. This is alarming because, about $15 \%$ of the population experience some type of food poverty and if those on low incomes are added, the figures rise to 35\%. Most of this wasted food goes to landfill. It is estimated that each kilogram $(\mathrm{kg})$ of food waste costs $€ 2$ (purchasing ingredients, energy to cook, labour to prepare, and disposal to landfill). This amounts to an average of $€ 1000$ per household in Ireland (about $€ 2000 /$ tonne). To reduce the volume may create financial savings by the avoidance of landfill levy charges. These have been rising from the initial €30/tonne in 2010, €50/tonne in 2011 and $€ 75 /$ tonne in 2012, to meet European Union Council Directive 1999/31/EC on the landfill of waste [17,48].

FW refers to raw or cooked food materials, including food loss before, during or after meal preparation in the household, as well as food discarded in the manufacturing/production, distribution, wholesale/retail and food service sectors (including restaurants, schools and hospitals, etc.). FW is a major vermin attractant, and source of odour emission, toxic gas emission and groundwater contamination in collection, transportation and landfill, owing to high organic concentration and moisture content [49]. FW can be highly variable depending on its source. Its composition differs significantly from one place to another. This can hinder its successful digestion on its own. It can also contain plastics, metals and other impurities $[11,16]$.

FOG comprises greasy by-products separated from wastewater from restaurants, hotels, institutional kitchens, meat processing plants, food industry, and dissolved air floatation of the WWTPs etc. Municipalities consider the release of FOG into the collection system/sewer lines to be illegal. Within sewer lines, it forms hardened solids (fatbergs) as a result of both chemical and physical changes, resulting in sewer overflow, reducing conveyance capacity, road diversions, and sometimes flooding of properties [51,52]. These cost millions of euros to municipalities every year in repairing, cleaning, and maintenance fees. According to Curran [52], fatbergs (FOG) are rampant in the UK with about 15 tonnes found in Kingston in 2013, which took six weeks to remove, costing $€ 20$ million to repair. It was estimated that FOG caused 50-75\% sewerage pipeline blockages. Accordingly, municipalities implement pre-treatment steps to aid the removal of grease from the kitchen waste streams. This is usually accomplished by using grease abatement devices called grease traps (typically $190 \mathrm{~L}$ in size and installed directly below the sink inside the food production facility), or grease interceptors (typically 3800-7500 L in size and installed below the ground and outside buildings [53]. These devices are pumped out at regular intervals to prevent the FOG from entering the sewerage system. The operational challenges with FOG include sludge floatation, inhibition of methanogenic and acetoclastic bacteria, substrate and product transport limitation, digester foaming, clogging of gas collection and handling systems, blockage of pipes and pumps [5,54-56].

According to Davidsson et al. [5] and Nghiem et al. [40], the high lipids content of FOG results in process instability because of inhibition of LCFAs. Therefore, co-digestion of FOG with sewage sludge or animal manure is a better choice. Because of its high methane potential of $0.7-1.1 \mathrm{~m}^{3} \mathrm{CH}_{4} / \mathrm{kg}$ VS [2], and the high theoretical methane potential of $0.9-1.4 \mathrm{~L} / \mathrm{g}$ at $65-70 \% \mathrm{CH}_{4}[5,55]$, the co-digestion of FOG with SS is more beneficial, especially when the waste is collected in-house. It is important to control the amount of FOG added to the mix to avoid high concentration of LCFAs production in the digester, as they can inhibit methanogenic activities $[1,2,6,10,12,57,58]$. High concentration of LCFA will cause operational 
problem during co-digestion $[12,59,60,62,63]$. There are operational challenges associated with FOG digestion such as foaming and biomass flotation related to adsorption of lipids onto biomass, and clogging in the liquid or gas systems $[45,64]$.

\section{Compositions and characteristics of FW}

The composition of FW varies with eating habits. Its characteristics in terms of carbohydrates, lipids and proteins differ considerably based on its components $[3,12,31,34,65]$. For example, bread, potatoes and flour are rich in carbohydrates; meat, fish and eggs and cheese are rich in protein. Fresh vegetables present an even composition of carbohydrate and protein content, as shown in Table 1. FW elemental compositions are commonly expressed in terms of available carbon $(\mathrm{C})$, hydrogen $(\mathrm{H})$, nitrogen $(\mathrm{N})$, oxygen $(\mathrm{O})$ and Sulphur $(\mathrm{S})$. The elemental composition of carbohydrates, proteins and lipids indicates that an important quantity of carbon is available in FW, which makes it highly degradable.

\section{Compositions and characteristics of FOG sludge}

The origins of the FOG determine the total solids and fat compositions. Long et al. [55] note that the composition and chemical characteristic of FOG can vary greatly depending on its origin, the abatement device configuration (size, inlet/outlet piping, number of baffles), and the device pumping frequency. The frequency of pump-out can influence its biochemical oxygen demand (BOD), and total solids (TS) variations [39,53]. Suto et al. [66] observe that waste cooking oil typically forms three layers whether in pipes, containers or abatement devices, which are primary (top floatable layer), organic-rich wastewater (middle aqueous layer and food particles) and other settled solids (bottom sludge layer). The volume of each

Table 1. Composition of different components of food waste as reported in literature (on \% dry weight/ matter.

\begin{tabular}{lcccc}
\hline Waste & Carbohydrates & Proteins & Lipids & \multicolumn{2}{c}{ References } \\
\hline Grain products & 74 & 12 & $0.7-2.0$ & {$[120]$} \\
MFC (meat-fish-cheese) & 12 & 55 & 33 & {$[121]$} \\
BP (bread-pasta) & 82 & 13 & 4 & {$[121]$} \\
Vegetables & 72 & 11 & 4 & {$[122]$} \\
Fruits & 94 & 3 & $<$ & {$[122]$} \\
Animal-derived food waste & $2-6$ & $70-75$ & $20-30$ & {$[123]$} \\
Cakes and pastries (Starbucks) & $30-60$ & $5-10$ & $10-40$ & {$[78]$} \\
Mixed food waste & 63.87 & 21.34 & 12.4 & {$[124]$} \\
Whole milk (powder) & 37.7 & 26.5 & 27.4 & {$[125]$} \\
Skim milk & 53 & 36 & - & {$[125]$} \\
Cheese & - & $25-35$ & $20-45$ & {$[125]$} \\
Legumes & & $23-29$ & $1.3-5$ & {$[126]$} \\
Fresh vegetables & b & 26.9 & 1.4 & {$[126]$} \\
Meat and bones & 27.1 & $70-75$ & $23-30$ & {$[127]$} \\
Egg (including shell) & $<1$ & 35 & 32 & {$[125]$} \\
Fish meat & 2 & 75.6 & 20.2 & {$[128]$} \\
Fruit & - & 4 & 2 & {$[129]$} \\
Bread & 83 & 14 & 2 & {$[127]$} \\
Potato & 84 & 1 & $<1$ & {$[127]$} \\
Rice & & 7.4 & $0.8-2.4$ & {$[125]$} \\
Flour & 76.3 & 12 & $<1$ & {$[127]$} \\
\hline
\end{tabular}

${ }^{a}$ Excluding soybeans which are composed by $41 \%$ protein, $19.6 \%$ lipids and $31.6 \%$ carbohydrates.

bainly spinach. 
layer will depend on the frequency of evacuation and the types of abatement devices or container used. Waste cooking oil collected from restaurants, hotels and other food outlet grease collection devices has a high fat content. Some studies $[37,55]$ have concentrated on unsaturated fat rather than saturated fat. Oleic acid was reported as the most common fatty acid found in grease trap abatement devices and WWTPs. The TS of FOG ranges from 2 to $22 \%$ before dewatering [37].

Table 2 shows the main characteristics of different FOG waste samples as reported in the literature on sewage sludge co-digestion with FOG at lab scale.

Table 2. FOG waste characteristics coming from different origins as reported in literature (DAF (dissolved air flotation), FL (floatable layer), AL (aqueous layer), SL (sludge layer).

\begin{tabular}{|c|c|c|c|c|c|c|c|c|c|}
\hline $\begin{array}{l}\text { Parame- } \\
\text { ters }\end{array}$ & $\begin{array}{l}\text { COD } \\
(\mathrm{g} / \mathrm{L})\end{array}$ & TS (g/L) & VS (g/L) & VS (\%TS) & $\mathrm{PH}$ & $\mathrm{C} / \mathrm{N}$ & TKN (g/L) & Fat (\%) & $\begin{array}{l}\text { Refer- } \\
\text { ences }\end{array}$ \\
\hline $\begin{array}{l}27 \text { different } \\
\text { restau- } \\
\text { rant } \\
\text { grease } \\
\text { samples }\end{array}$ & $\begin{array}{c}\mathrm{FL}: 478 \\
\mathrm{AL}: 66.2\end{array}$ & - & - & 96.2 & - & - & - & 48.6 & [66] \\
\hline $\begin{array}{l}\text { Samples } \\
\text { from } \\
\text { two food } \\
\text { service } \\
\text { establish- } \\
\text { ments in } \\
\text { NC }\end{array}$ & $\begin{array}{c}\mathrm{FL}: 303.4 \\
\mathrm{AL}: 66.2\end{array}$ & - & - & 100 & $3.9-6.2$ & - & - & - & [51] \\
\hline $\begin{array}{l}\text { Grease trap } \\
\text { sludge }\end{array}$ & - & 159 & 158 & 99.4 & 5.6 & - & - & - & [37] \\
\hline DAF sludge & - & 78 & 68 & 87.2 & 6.8 & & & & [37] \\
\hline $\begin{array}{l}\text { Post } \\
\text { flotation } \\
\text { sludge }\end{array}$ & 1207 & 219 & 185 & 84.4 & - & 8.8 & 2 & 6 & [63] \\
\hline $\begin{array}{l}\text { FOG (res- } \\
\text { taurants) }\end{array}$ & 2698 & 777 & 777 & 100 & 5 & - & - & - & {$[61,130]$} \\
\hline $\begin{array}{l}\text { FOG (res- } \\
\text { taurants) }\end{array}$ & 1510 & 258 & 257 & 99.6 & - & - & - & - & [62] \\
\hline $\begin{array}{l}\text { FOG (res- } \\
\text { taurants) }\end{array}$ & 1500 & 968 & 955 & 98.7 & - & - & - & - & [58] \\
\hline $\begin{array}{l}\text { FOG (meat } \\
\text { pro- } \\
\text { cessing } \\
\text { plants) }\end{array}$ & - & 25 & 25 & 100 & 5.1 & - & - & - & [54] \\
\hline $\begin{array}{l}\text { FOG DAF- } \\
\text { treatment } \\
\text { plant }\end{array}$ & - & 173 & 170 & 98.2 & 4.4 & - & - & - & [5] \\
\hline $\begin{array}{l}\text { FOG DAF- } \\
\text { treatment } \\
\text { plant }\end{array}$ & 298 & 146 & 123 & 84.2 & - & 20 & 4287 & 47 & [12] \\
\hline $\begin{array}{l}\text { FOG DAF- } \\
\text { treatment } \\
\text { plant }\end{array}$ & 321 & 160 & 143 & 89.4 & - & 39 & 3556 & 100 & [12] \\
\hline $\begin{array}{l}\text { FOG DAF- } \\
\text { treatment } \\
\text { plant }\end{array}$ & 258 & 126 & 101 & 80.1 & - & 23 & 3166 & 38 & [12] \\
\hline $\begin{array}{l}\text { FOG DAF- } \\
\text { treatment } \\
\text { plant }\end{array}$ & 177 & 75 & 63 & 84 & - & 10 & 3428 & 15 & [12] \\
\hline $\begin{array}{l}\text { FOG DAF- } \\
\text { treatment } \\
\text { plant }\end{array}$ & 196 & 96 & 86 & 89.6 & 5.5 & 42 & 2200 & - & [61] \\
\hline FOG & - & 32 & 30 & 93.8 & 4.2 & 22 & - & - & [68] \\
\hline
\end{tabular}




\section{Co-digestion of FW with SS}

Apart from the feedstock compositions, a wide range of successful results concerning the co-digestion of SS with FW demonstrate factors such as the organic loading rate (OLR), sludge composition (primary, secondary or mixed), digester configuration, mixing conditions and temperature range [1]. Many researchers have reported the benefits of co-digestion of SS with FW for improved methane production and dilution of toxic compounds $[26,32,34,68]$. Table 3 shows a summary of studies of methane yield during co-digestion of SS, WAS with FW. Most researchers adopted continuous stirred tank reactors, but a few adopted two-phased anaerobic digestion, and anaerobic sequence batch reactors. The parameters for these benefits are of equal importance, especially when it comes to increasing the co-digestion performance. Table 3 shows that the higher the OLR, the higher the methane production. The volatile solids (VS) removal rate (efficiency) seems to be a function of the percentage of the FW added to the mixture on VS basis $[41,68]$.

In addition, thermophilic anaerobic co-digestion showed higher biogas production than mesophilic co-digestion in the past studies. Cavinato et al. [26] found an increase in methane production of $160 \%$ when operation the digester under thermophilic temperature condition followed by a mesophilic digester with OLR of $2.21 \mathrm{~kg} / \mathrm{m}^{3} \mathrm{~d}$, using a 75:25 SS:FW mixture ratio on (on VS basis). The same trend was observed in other studies investigated as shown in Table 3.

The methane yields were found to increase significantly with an increased percentage of FW in mixtures with SS, illustrating the value of the co-digestion process $[8,41]$. FW is a highly biodegradable co-substrate, which, until a certain threshold limit, improves the biogas production of the sewage sludge digesters just by increasing the OLR. Any addition of FW whether above or below the optimum mixing ratio can limit the digestion and reduction in biogas yields, or even result in a complete failure through system instability $[3,11,70]$. Evaluating the economic and environmental suitability of using OFMSW as a substrate in two German WWTPs, Krupp et al. [71] argued that using OFMSW as sewage sludge co-substrate was the more advantageous solution when compared to OFMSW composting and mono-digestion.

Table 3. Comparative studies of methane yield during co-digestion of sewage sledge (SS), WAS with food waste (FW).

\begin{tabular}{lccccccc}
\hline $\begin{array}{l}\text { Sludge/sub- } \\
\text { strate }\end{array}$ & $\begin{array}{c}\text { Mixing ratio } \\
(\%)\end{array}$ & $\begin{array}{c}\mathrm{T}\left({ }^{\circ} \mathrm{C}\right) \\
\text { SS + FW }\end{array}$ & $\begin{array}{c}\text { Digester } \\
\text { type }\end{array}$ & $\begin{array}{c}\text { OLR }(\mathrm{kg} / \\
\left.\mathrm{m}^{3} \mathrm{~d}\right)\end{array}$ & $\begin{array}{c}\mathrm{SMP}\left(\mathrm{m}^{3} \mathrm{CH}_{4} /\right. \\
\mathrm{kg})\end{array}$ & $\begin{array}{c}\text { Improve- } \\
\text { ment }\end{array}$ & $\begin{array}{c}\text { Refer- } \\
\text { ences }\end{array}$ \\
\hline SS + FW & $50: 50$ & 35 & ASBR & $2.40(\mathrm{VS})$ & $0.12-0.22(\mathrm{VS})$ & $\times 1.85$ & {$[73]$} \\
SS + FW & $60: 40$ & 35 & ASBR & $3.50(\mathrm{VS})$ & $0.18(\mathrm{VS})$ & - & {$[131]$} \\
*WAS + Biowaste & $0.9: 1$ & 35 & CSTR & $7.20(\mathrm{VS})$ & $0.33(\mathrm{VS})$ & $\times 1.72$ & {$[50]$} \\
FW (mono) & $1: 1$ & 35 & CSTR & $4.80(\mathrm{VS})$ & $0.42(\mathrm{VS})$ & - & {$[132]$} \\
SS + FW & $75: 25$ & 35 & TPAD & & $0.23-0.44(\mathrm{VS})$ & $\times 1.87$ & {$[100]$} \\
WAS + FW + FWW & $50: 20$ & 35 & CSTR & n.d & $0.27-0.33(\mathrm{VS})$ & $\times 1.2$ & {$[133]$} \\
WAS + FW & 100 & 37 & CSTR & 1.20 & $0.56-2.04(\mathrm{VS})$ & - & {$[34]$} \\
PS + WAS + FW & $29: 71$ & 35 & CSTR & 1.22 & $0.11-077(\mathrm{VS})$ & & {$[26]$} \\
WAS + FW & $10: 90$ & 35 & CSTR & n.d & $0.95-3.66(\mathrm{VS})$ & $\times 3.85$ & {$[132]$} \\
WAS + OFMSW & n.d & 37 & CSTR & n.d & $0.21(\mathrm{VS})$ & $\times 2.28$ & {$[134]$} \\
\hline
\end{tabular}

Notes: ORL organic basis units in brackets, SMP organic basis units in brackets, n.d: non-detailed, $\times$ : multiplication factor to the SMP of mono-digestion considering the same units shown for each study. ${ }^{*}$ WAS: Waste Activated Sludge. 
It was also reported that the improved carbon to nitrogen $(\mathrm{C} / \mathrm{N})$ ratio and kinetic reactions achieved by the addition of FW to SS were prerequisites for improving methane yield [72]. Some researchers have suggested that the optimum $\mathrm{C} / \mathrm{N}$ for digestion performance is in the range of 20-30; others have equally demonstrated that digestion can be successfully performed under a wider range of $\mathrm{C} / \mathrm{N}$ ratios [8,41,73-76]. Palatsi et al. [6] and Wang et al. [41] argued that any $\mathrm{C} / \mathrm{N}$ ratio more than 30 will result in instability, mainly through nutrient deficiency. This will severely affect microorganisms' activity, thereby leading to lower substrate removal and methane production. But if the $\mathrm{C} / \mathrm{N}$ ratio is less than 6 , it will negatively affect the digestion process, chiefly as a result of low carbon availability in combination with high ammonia $\left(\mathrm{NH}_{3}\right)$ concentration, which can cause toxicity to anaerobic microorganisms [32,77].

Generally, SS is characterised by a low $\mathrm{C} / \mathrm{N}$ in the range of $6-9$, whereas, the addition of FW having high $\mathrm{C} / \mathrm{N}$ ratio (18-22) can improve the ensuing mixtures [29,74,78]. They reported an improvement of $\mathrm{C} / \mathrm{N}$ in the range of 6-15. Wang et al. [41] submitted that in addition, FW provides essential carbon to sewage digestion performance, mainly because of its influence on the process kinetics. In anaerobic digestion microbiology, hydrolysis has been described as rate-limiting steps, because SS is rich in proteins (30\% DM) by composition, and also has a lower hydrolytic potential than carbohydrates and lipids [34,76]. Therefore, the addition of easily degradable FW, has been reported to improve the degradation efficiency and speed up the hydrolysis of SS, because of the faster growth of anaerobic microorganisms [32,41]. A faster grow rate of the microorganisms will result in a higher hydrolytic rate and, thus, a higher acidification and methanogenesis potential $[11,23]$. Therefore, the co-digestion of FW with SS will improve not only the kinetic coefficients of hydrolysis, but also the overall performance. Further, temperature increase can result in even better kinetics. Angelidaki and Sanders [79] concluded that the effect of temperature on the hydrolysis kinetic originates from the combined effect of hydrolytic enzymes, bacteria growth and solubility of the substrate on the improved activity.

Co-digestion of SS with FW allows the WWTPs to increase their revenue streams from the increase renewable energy generation (biogas). According to Defra [21], by generating additional renewable energy, the water industry would be able to increase its revenue (gate fee), by reducing their electricity bills and also by selling the surplus energy to the grid. FW addition will also dilute some potential toxic compounds such as heavy and light metal ions and other organic compounds $[14,16,56,80]$. SS contains a high amount of metals and this may affect the digestion process. The co-digestion of SS with FW can reduce the inhibitory effect of these toxic compounds [81]. The resulting efficient dilution would not only increase the degradation efficiency of SS, but also the biogas yields.

FW degradability through AD has been widely studied [3,78,82-84]. In many studies, it was reported that the digestion of FW was limited either owing to the lack of sufficient nutrients such as nitrogen, phosphorous and to a smaller extent metals, or to VFAs accumulation resulting from its extremely high degradability $[2,83]$. FW was successfully digested in other cases, but only after modifications of the digester: chemicals, the introduction of pre-treatment steps, the recirculation of nutrients through leachate or increases in temperature $[13,82,83,86]$. Most of these studies were experimental, with the implementation of $\mathrm{AD}$ of FW at full scale reported to be limited and problematic [2,56,87]. de Baere [88] provides a survey of AD's effect on MSW across Europe, with emphasis on FW. 


\section{Co-digestion of FOG with SS}

FOG is desirable for co-digestion. It has a high methane potential $\left(1 \mathrm{~m}^{3} \mathrm{CH}_{4} / \mathrm{kg} \mathrm{VS}\right)$. Much work has suggested the increase in methane through co-digestion with SS. Most studies were centred on FOG waste produced in the dissolved air flotation unit of the WWTP $[12,37,39,89]$. Several researchers have investigated the FOG waste coming from meat processing factories co-digested with SS $[64,90,91]$. Some have also investigated the restaurants' grease-trap waste under mesophilic anaerobic co-digestion with SS $[39,58]$. Carrere et al. [93] and Pastor et al. [94] investigated restaurant fatty wastewater. These studies concern used oils from the restaurants co-digested in a mesophilic condition with SS (Table 4).

Luostarinen et al. [54] reported a 60\% increase in methane yield when grease from a meat plant was co-digested with SS. Wan et al. [95] reported an increase of $137 \%$ in methane production, when a grease content of $64 \%$ on a VS basis was added. Astals et al. [2], using FOG as a co-substrate at a full-scale digester, reported a $50 \%$ increase in biogas production. Kabouris et al. [92] investigated FOG as a co-substrate and achieved a significant result in biogas production. Silvestre et al. [12] observed a methane yield of $138 \%$ when a grease trap with $23 \%$ grease content on a VS basis was added with SS.

As shown in Table 4, FOG can come from two sources: from industrial processes (including other treatment plants) and from the same WWTP. In the treatment plants,

Table 4. Comparative studies of methane yield during co-digestion of SS and FOG.

\begin{tabular}{|c|c|c|c|c|c|c|c|}
\hline Sludge/substrate & $\begin{array}{l}\text { Mixing } \\
\text { ratio (\%) }\end{array}$ & $\mathrm{T}\left({ }^{\circ} \mathrm{C}\right)$ & $\begin{array}{l}\text { Digester } \\
\text { type }\end{array}$ & $\begin{array}{l}\mathrm{OLR}(\mathrm{kg} / \\
\left.\mathrm{m}^{3} \mathrm{~d}\right)\end{array}$ & $\begin{array}{c}\mathrm{SMP} \\
\left(\mathrm{m}^{3} \mathrm{CH}_{4} /\right. \\
\mathrm{kg})\end{array}$ & $\begin{array}{l}\text { Improve- } \\
\text { ment/inhibi- } \\
\text { tion }\end{array}$ & References \\
\hline $\begin{array}{c}\text { PS:WAS + FOG } \\
(74: 26)\end{array}$ & $100: 0$ & 35 & CSRT & 1.90 (VS) & 0.56 (VS) & - & [89] \\
\hline $\begin{array}{c}\text { PS:WAS + FOG } \\
(74: 26)\end{array}$ & $80: 20$ & 35 & CSRT & 2.90 (VS) & 0.98 (VS) & $\times 1.75$ & [89] \\
\hline PS:WAS + FOG & $40: 60$ & 35 & CSRT & 3.10 (VS) & 1.72 (VS) & $\times 3.07$ & [89] \\
\hline $\begin{array}{c}\text { PS:WAS + FOG } \\
(74: 26)\end{array}$ & $60: 40$ & 35 & CSRT & 3.50 (VS) & 1.43 (VS) & $\begin{array}{c}\times 2.55 / \text { LCFA } \\
\text { foaming }\end{array}$ & [89] \\
\hline $\begin{array}{c}\text { PS:WAS + FOG } \\
(74: 26)\end{array}$ & $70: 30$ & 35 & CSRT & 1.60 (VS) & 0.35 (VS) & Reduced & [89] \\
\hline $\mathrm{SS}+\mathrm{FOG}$ & $77: 23$ & 35 & CSRT & 1.60 (VS) & 0.37 (VS) & $\times 1.48$ & {$[12]$} \\
\hline SS + grease trap & $77: 23$ & 36 & CSRT & 1.58 (VS) & 0.63 (VS) & $\begin{array}{c}\times 1.27 / L C F A \\
@ 30 \%\end{array}$ & [62] \\
\hline $\begin{array}{c}\text { PS:WAS + FOG } \\
(50: 50)\end{array}$ & $100: 0$ & 35 & CSRT & 3.0 (VS) & 0.83 & - & [5] \\
\hline $\begin{array}{c}\text { PS:WAS + FOG } \\
(50: 50)\end{array}$ & $90: 10$ & 35 & CSRT & 3.0 (VS) & 1.08 & $\times 1.3$ & [5] \\
\hline $\begin{array}{c}\text { PS:WAS + FOG } \\
(50: 50)\end{array}$ & $100: 0$ & 52 & CSRT & 2.5 (VS) & 0.68 & $\begin{array}{l}\text { Reduced by } \\
\times 0.82\end{array}$ & {$[5]$} \\
\hline $\begin{array}{c}\text { PS:WAS + FOG } \\
(50: 50)\end{array}$ & $90: 10$ & 52 & CSRT & 2.4 (VS) & 0.83 & Same & {$[5]$} \\
\hline $\begin{array}{c}\text { PS:WAS + FOG } \\
(50: 50)\end{array}$ & $70: 30$ & 52 & CSRT & 4.45 (VS) & 2.23 & $\times 2.70$ & {$[5]$} \\
\hline $\mathrm{SS}+\mathrm{FOG}$ & $36.6: 63.6$ & 35 & CSRT & 11 COD & $\begin{array}{l}0.31 \\
\text { (COD) }\end{array}$ & - & [15] \\
\hline WAS + FOG & $64: 36$ & 37 & CSRT & 2.34 (VS) & 0.60 (VS) & $\times 2.37$ & {$[95]$} \\
\hline WAS + FOG & $48: 52$ & 36 & CSRT & 1.2 (VS) & 0.55 (VS) & ×2.07/@74\% & {$[61]$} \\
\hline SS + used oil & $80: 19.4$ & 38 & CSRT & 0.91 (VS) & 0.47 (VS) & $\begin{array}{c}\text { Inhibition at } \\
53 \%\end{array}$ & [94] \\
\hline $\mathrm{SS}+\mathrm{FOG}$ & 99.8:0.2 & 34 & CSRT & 0.77 (VS) & 0.30 (VS) & Adsorption & [39] \\
\hline $\mathrm{SS}+\mathrm{FOG}$ & $34.5: 65.5$ & 37 & CSRT & 2.16 (VS) & 0.75 (VS) & $\begin{array}{l}\times 4.18 / \text { inhibi- } \\
\text { tion @ 83.5\% }\end{array}$ & [58] \\
\hline
\end{tabular}

Notes: ORL: organic basis units in brackets, SMP: organic basis units in brackets, n.d: non-detailed, $\times$ : multiplication factor to the SMP of mono-digestion considering the same units shown for each study. 
FOG represents $25-40 \%$ of the wastewater total chemical oxygen demand and it is usually removed to about 50-90\%, prior to biological treatments [96]. It saves money to treat the FOG sludge by using it as a co-substrate with sewage sludge.

Noutsopoulos et al. [89] reported an increase of $285 \%$ in biogas production by comparing the digestion of $40 \%$ SS and $60 \%$ FOG mixture on a VS basis $\left(2.1 \mathrm{~kg} \mathrm{VS}_{\text {fog }} \mathrm{m}^{3} / \mathrm{d}\right)$ with a mono-digester of SS, which had an OLR of $1.9 \mathrm{~kg} \mathrm{VS} \mathrm{m}^{3} / \mathrm{d}$. The co-digestion failed when the OLR of the FOG was further increased to $2.5 \mathrm{~kg} \mathrm{VS}_{\text {fog }} \mathrm{m}^{3} / \mathrm{d}$. Alanya et al. [15] using FOG from a primary settler and the scum from a concentration tank, co-digested with SS, obtained an increase in biogas production of $410 \%$, with similar FOG (OLR of $\left.2.4 \mathrm{~kg} \mathrm{VS}_{\text {fog }} \mathrm{m}^{3} / \mathrm{d}\right)$. Davidsson et al. [5], using a lower OLR $\left(0.7 \mathrm{~kg} \mathrm{VS}_{\text {fog }} \mathrm{m}^{3} / \mathrm{d}\right)$ and Silvestre et al. [12] similarly $\left(0.6 \mathrm{~kg} \mathrm{VS}_{\text {fog }} \mathrm{m}^{3} / \mathrm{d}\right)$ also recorded a significant increase in biogas production $(150 \%)$ and $(210 \%)$, when compared to the SS mono-digester. The differences in these results can be attributed to the digesters' operational conditions, the adaptation periods, the characteristics of the feedstock (input materials) and the anaerobic biomass. Comparable results were also obtained with FOG coming from other origins.

According to Mata-Alvarez et al. [84], there is no clear threshold for FOG OLR. This is because several safe co-digestion performances with high biogas yields have been reported for $\mathrm{OLR}_{\text {fog }}$ up to $0.8 \mathrm{~kg} \mathrm{VS}$ fog $\mathrm{m}^{3} / \mathrm{d}$. The degradation products, LCFAs, may severely inhibit methanogenesis. Contrary to early studies, the inhibition (LCFA), which was long assumed irreversible, has lately been proved reversible $[38,51,57]$, because of the increasing consumption of acetate and butyrate, an indication of recovery [97]. In addition, when digesting lipidrich materials, a lag phase is usually observed between LCFA and methane production [61].

It seems that FOG with an original total solids (TS) of 1-2\% does not favour incineration, even though the energy content in the waste is very high, with VS content of over 95\% [54]. But, if thickened to a TS $>5 \%$, it can be suitable for co-digestion. The single-substrate digestion of SS from FOG (grease trap) is unwise since long-chain fatty acids are known to inhibit anaerobic microorganism $[55,59]$. It was reported that thermophilic conditions in the AD led to inhibition at much lower concentrations of oleate than in mesophilic conditions [29].

\section{Limitations and constraints of SS co-digestion with FW and FOG}

The key technical challenges limiting anaerobic co-digestion of sewage sludge with organic wastes will now be discussed briefly. The slow degradation process (FOG) will result in inefficiency of the system. The substrates are typically made of complex structures that are difficult for bacteria to access and some can contain non-degradable substances (lignin). This leads to a long retention time inside the digester; thus, a slow and inefficient process. Although there is a range of pre-treatment options, the wrong selection can lead to high investment costs and high operational costs. Therefore, the right pre-treatment option should be an $\mathrm{AD}$ specific process. Poor management of nutrients and the presence of toxic substances in the substrates is another technical challenge. The variability of FW and FOG and their composition limits their co-digestion with SS to some extent, because of the imbalance they can cause the anaerobic digestion systems. The dynamics of AD processes are complex. There is need for a stable digestion system if optimum biogas is to be produced, but the microorganisms acclimatised with some mixtures, and any changes in the mixtures may result in changes in process reactions and digestion instability. The specific methane production potential $h$ may also vary with the seasonal variation of FW $[13,26,34,51,98]$. 
Some researchers reported an accumulation of the light and heavy metals ( $\mathrm{Zn}, \mathrm{Pb}$ and $\mathrm{Ni}$ ) and other improper materials in the digester, especially when mechanical-sorted OFMSW was used as co-substrate [8,99]. According to Chen et al. [87], light metal ions and biodegradation intermediates play important roles in process performance. They can also cause toxicity in anaerobic digestion. There may be adverse changes by reducing the bacteria growth and changes in the microbial community. Therefore, a slight addition of FW to the mixes (SS/FW) might increase the concentration of these light metal ions, making them toxic to the anaerobic microbial community.

Light metal ions (cations) in FW are essential for the growth of anaerobic microorganisms, which at high concentrations can be toxic in the digestion process, through osmosis [34]. Any FW rich in vegetable co-digested with sewage sludge will likely show an increase in potassium $\left(\mathrm{K}^{+}\right)$, which may inhibit the digestion process; and likewise, FW containing sodium $\left(\mathrm{Na}^{+}\right)$may be toxic to the bacteria [26]. The main biodegradation intermediates of anaerobic digestion are VFAs and ammonia $\left(\mathrm{NH}_{3}\right)$. Therefore, accumulation of the intermediates beyond certain limits in the digester can cause toxicity disruptions of the co-digestion process. There is an increase in VFA concentration initially when FW is co-digested with SS because of rapid acidification of soluble organic compounds that are present in FW $[13,44,100]$. There is no definite level for acceptable VFAs in the digester, but VFAs of $6000 \mathrm{mg} / \mathrm{l}$ can be present in the digester without being toxic provided the $\mathrm{pH}$ is kept within optimal range [101].

The lipids content in FOG and FW will affect the digestion process owing to excessive production of LCFAs; which are proven to be toxic to anaerobic bacteria $[8,103]$. The levels at which LCFAs become toxic vary widely, depending on which acids are predominant in the digester. The main cause of $\mathrm{NH}_{3}$ production and accumulation in the digester is the degradation of FW as they are rich in protein [77]. In the digester, $\mathrm{NH}_{3}$ and ammonium ion $\left(\mathrm{NH}_{4}^{+}\right)$are always present. A large value of $\mathrm{NH}_{4}^{+}$is associated with greater buffering capacity of the digestate, increasing the digester's stability. Appels et al. [105] shows that $\mathrm{NH}_{4}^{+}$can inhibit the activity of methanogens and hence reduce the biogas production when the $\mathrm{NH}_{4}^{+}$concentration is above $3.0 \mathrm{~g} \mathrm{~L}^{-1}$. In the literature, it seems that $\mathrm{NH}_{3}$ was reported to be more inhibitory than $\mathrm{NH}_{4}^{+}$because it can penetrate through the cell membranes $[13,105-107]$. The level at which $\mathrm{NH}_{3}$ concentration becomes inhibitory in the digesters is uncertain. Interestingly, Heo et al. [74] and Arhoun et al. [108] reported that a mixture with a higher percentage of food waste than sewage sludge may not likely have ammonia inhibition, because of the availability of higher carbon in the mix.

There are operational constraints associated with handling and sorting of FW. FW must be free of impurities and unwanted materials prior to co-digestion with SS. Impurities in FW such as plastics, metals, glass and other packaging parts are likely to cause serious operational problems and affect co-digestion performance and the WWTP. Plastics can cause serious clogging in the mechanical system and wear out pumps and form the top layer inside the reactors. The presence of plastics (phthalates) can affect the quality of the digestate and make it unacceptable as soil conditioner in agricultural land $[3,8]$. The presence of metals can also cause clogging in the conveyor line. All these can lead to higher operational costs, loss in the important fraction of FW during pre-treatment process, and reduction in biogas yield.

Animal by-products regulation (ABPR) is another impediment to co-digesting sewage sludge with FW. The water industry is required to have this permit to process FW. Any FW 
processing that has been contaminated by meat and other animal materials falls within ABPR. The regulation defines three categories of animal by-products (ABP) which includes FW originating from households, restaurants and catering facilities, with category three being the least harmful [18,109-111]. This was transposed in Ireland under European Union (ABP) Regulation S.I No 187 of 2014 [48,112]. The ABPR permit requirements are that FW must firstly be pre-treated to ensure the removal of packaging material and other impurities and secondly, be pasteurised before being added to the digester [112].

The main aim of the ABPR is to sanitise food production, FW and to prevent transfers of pathogens. According to Defra [21], it is likely that the ABPR covers the use of co-digestion. In Ireland, the personnel responsible for ABPR in the Department of Agriculture, Food and Marine (DAFM) need to be informed and application must be made in line with the conditions. The process is done in three stages; before construction, before operation and validation of operation (when the plant is commissioned).

\section{Future research suggestion and prospect of application in Ireland}

The limitations associated with these three substrates (FOG, FW and SS), mainly the technical challenges and increased costs from chemical additions, increases in temperature and proper digestion management, and increasing concerns about the reliability of mono-digestion of FW have led to the investigation of co-digestion with SS as a better alternative. Further, wastewater treatment processes are very energy intensive, and could only benefit from initiatives to reduce their costs [113]. Sustainability requires adopting a systems approach with integrated solutions, rather than addressing single issues in isolation. Thus, a WWTP can serve as an energy producer, rather than end-of-pipe solution to clean wastewater.

There is growing interest in biogas, and there is large untapped potential to produce it both as a fuel in transport applications and for heating. According to Iacovidou [65], co-digestion is a breakthrough for the wastewater sector and its implementation needs an interdisciplinary approach. Care must be taken to avoid overloading the digesters to allow smooth process without problems. Overloading can cause failure of the whole process or reduction in biogas production, pipe blockages, foaming, and insufficient mixing of the substrates in the digester $[40,51,59,114]$.

In Ireland, the co-digestion of FW with SS is almost non-existent and the few farm-based plants co-digest animal manure with municipal solid wastes, energy crops and glycerin from biodiesel plants. There are only three small-scale anaerobic digestion facilities in Ireland; McDonnel Farm Biogas Limited, Ballyshannon Recycling Limited and Bio-Energy and Organic Fertilizer (BEOFS). The current operational and regulatory framework makes anaerobic digestion complicated, because both FW and SS are covered by different regulatory regimes. The regulation becomes even more complicated when SS is co-digested with FW with the process falling between two sets of regulations [48]. There are issues with getting waste management license requirements, quality of the co-digestate and getting the renewable energy generation credits. All these problems impede the adaptation of co-digestion of SS with FW by the water industry in Ireland.

In Ireland, anaerobic digestion fell within the EU Pollution Prevention and Control provisions, known in Ireland as the Integrated Pollution Control system which came into effect in 1994. It was replaced by the Integrated Pollution Prevention and Control (IPPC) system, 
introduced in Ireland in 2004, and implemented through the Environmental Protection Agency (EPA) (IPPC) Regulation 2013 S.I 283 of 2013 [115]. The IPPC Directive itself regulates the quantity and nature of pollutants emitted into the environment by the licensee, ensures that energy is used more efficiently, applies the precautionary principle and the polluter pays principle, prevents accidents, and makes improvements in all processes [112].

As a result, a Waste Management License was required under the EPA Act 1992, in order to operate an anaerobic digestion plant, where sewage sludge will be digested with household waste, industrial and commercial wastes EPA [48]. A Waste Management License is required for the delivery, treatment and disposal of these wastes. Even in the UK, where regulations are similar to Ireland, these regulations (IPPC permit and Waste Management License) were merged to simplify regulation under Environmental Permit Regulations, to control the water industry. The control affects not only the size of the combined heat and power (CHP) plants, but also co-digestion of SS and FW, and the use of the biogas produced, and the storage and spreading of the digestate for a safer and cleaner environment $[11,22,48,116]$. The EPA waste permit in Ireland takes several months to process depending on the size of the plant. It is renewable annually, by a fresh application, which increases the water industry's costs.

In Ireland, an application for grid connection must be submitted to the Commission for Energy Regulation (CER). This is a complicated procedure and has considerable costs attached. CER provides licensing for construction and operation of CHP generator, but units under $1 \mathrm{MW}$ are automatically licensed by order. The final hurdle lies with the Department of Communication, Energy and Natural Resources, which grants Renewable Energy Feed in Tarif (REFIT), for which AD-CHP application is up to $15 \mathrm{ct} / \mathrm{kWh}$. This can only be done after planning permission is granted and grid connection offer has been issued. David McDonnell, of McDonnell Farm Biogas Limited, states in a REFIT report by the Sustainable Energy Authority of Ireland (SEAI) [19], that it takes a minimum of two years to get the project from inception to completion. This long delay would deter investors in such a project.

Furthermore, the digestate from the co-digestion of SS with FW and FOG may require a potentially very expensive permit for disposal via land application. This is because it was not considered a waste digestate in the revised Waste Framework Directive and therefore, it is not acceptable for application to land directly [110]. According to the Chartered Institution of Water and Environmental Management [117], the regulation that governs the production and use of such co-digestate is currently not clear and needs to be defined. This raises the question of what to do with the ensuing huge amount of co-digestate if not otherwise managed. All these problems of definition and procedure can cause impede developments in co-digestion in the water industry.

Waste generally should be considered as a resource and an economic opportunity. Co-digestion can help Ireland to reduce the amount waste going to landfills and a means to reduce greenhouse gas (GHG) emissions, prevent climate change, reduce electricity generation from fossil fuels, and thus create a sustainable environment. The relevant stakeholders and the regulators should work together, to support changes in regulatory frameworks necessary for the application of co-digestion of SS with FW and FOG.

There should be encouragement of all the WWTPs in Ireland to accept FW and FOG as co-substrates with their SS to increase biogas production, earn supplementary revenue, become energy self-sufficient, and improve their process performance. At present, WWTPs 


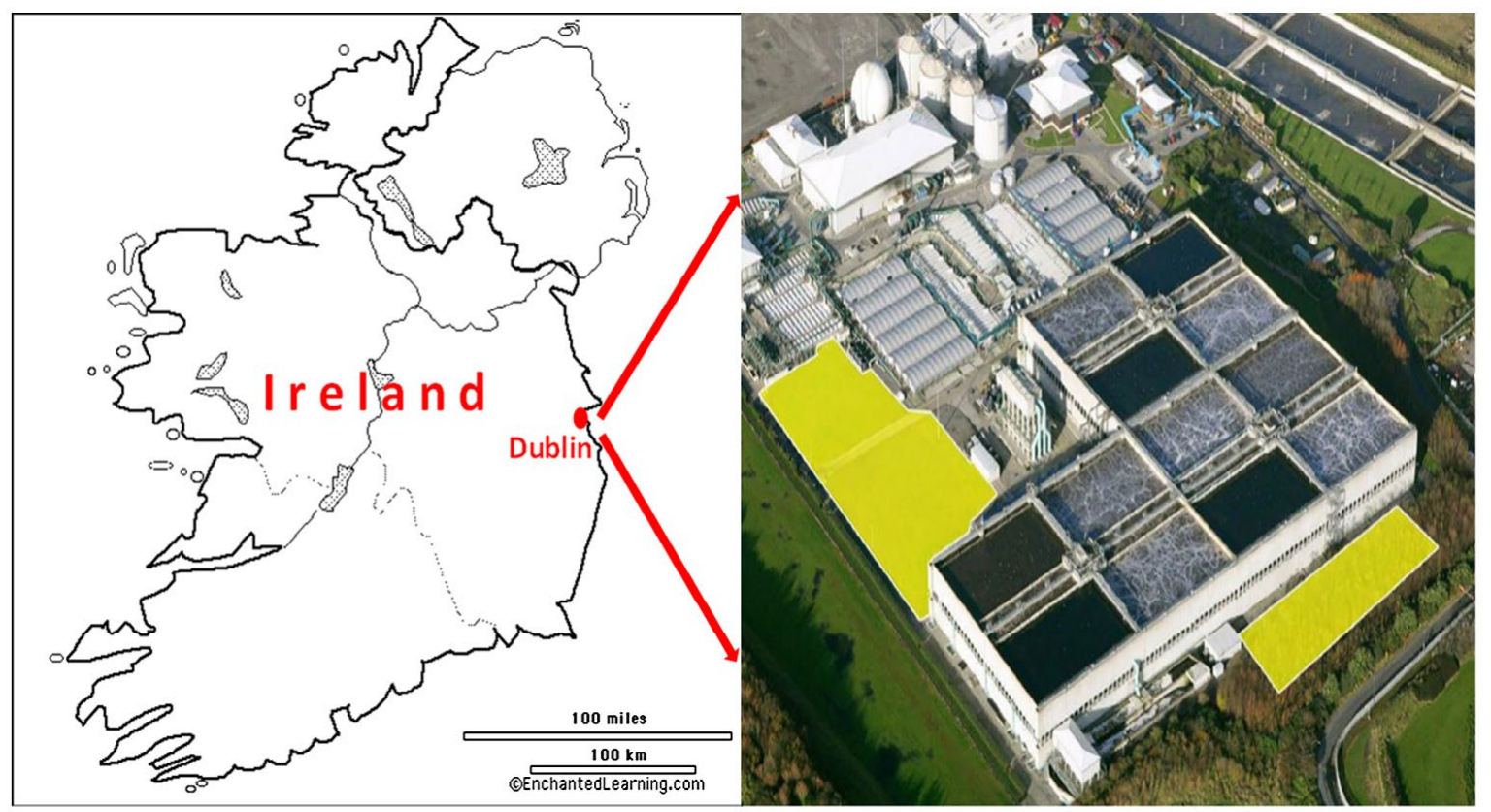

Figure 1. General view of Ireland and the Ringsend WWTP $[118,119]$.

in Ireland do not accept FW and FOG and their excess capacity is underused. Change could begin with Ringsend WWTP, as discussed below.

Ringsend WWTP is modelled on the design, build, and operate contract, undertaken to provide up to tertiary treatment for a 1.7 million population equivalent (P.E.) (Figure 1). Operation began in 2003 following construction which started in 1999. Ringsend is home to the largest double decker sequencing batching reactors design in the world and is also essential to Dublin Bay's blue flag status. The plant used several innovative technologies to deal with the large pollution load on a constrained site. Sewage sludge is treated using the Cambi Thermal Hydrolysis Process and anaerobic digestion (AD) before being thermally dried $[118,119]$. The installed capacity of the plant is $120,000 \mathrm{tDS} / \mathrm{yr}$ of sewage sludge, with biogas yield of average of $410 \mathrm{~m}^{3} / \mathrm{tDS}$. Currently, the anaerobic digestion produces $45,000 \mathrm{~m}^{3} /$ day of biogas. This is used to fuel boilers and to generate electricity and recover heat through the CHP system, which can generate more than $2 \mathrm{MW}$ of electricity, more than $50 \%$ of the heat and electricity required at the plant. The CHP system also generates electricity from natural gas for the plant's total energy demand. A total of $4 \mathrm{MW}$ of capacity is installed at the plant $[118,119]$. More details of the plant can be found from Celtic Anglian Water website (CAW) [118].

\section{Conclusions}

The review found that co-digestion of SS with FW and FOG provides an opportunity to increase biogas production especially from the existing biogas plant at the WWTPs. There is need for further research on the specific OLR which can be used to determine accurately the right quantity of organic wastes which can be added to a digester before there is potential for digester failure. This is because there is no agreed OLR specified for optimum results from the literature, probably because of different operating conditions. 
The incentive for renewable energy production in Ireland is the lowest amongst the EU countries which is just $15 \mathrm{ct} / \mathrm{kWh}$ as compared with Germany $(28 \mathrm{ct} / \mathrm{kWh})$, United Kingdom $(20 \mathrm{ct} / \mathrm{kWh})$ and France $(25.78 \mathrm{ct} / \mathrm{kWh})$. There should therefore be an urgent review in order to encourage the needed investment in the area of renewable energy generation, and open doors to a competitive market for digestate and energy supply within the country. The regulations and permit system should be simplified. Discrepancies among the bodies in charge should be eliminated, for the benefit of the environment.

If carefully applied, co-digestion can deliver beneficial synergies for the water industry and authorities responsible for food waste management. It is proposed that all relevant stakeholders and regulators should support changes to current regulatory frameworks to open a way forward for co-digestion in Ireland.

\section{Acknowledgement}

The first author acknowledges the support from the Civil Engineering Department of University College Dublin, scholarship support from Student Universal Support Ireland (SUSI) and Université de Toulouse, Mines Albi, CNRS UMR 5302, Centre RAPSODEE, Campus Jarlard, Albi, F-81013 cedex 09, France.

\section{Disclosure statement}

No potential conflict of interest was reported by the authors.

\section{References}

[1] Mata-Alvarez, J., Dosta, J., Macé, S. and Astals, S., 2011, Codigestion of solid wastes: A review of its uses and perspectives including modeling. Critical Reviews in Biotechnology, 31, 99-111.

[2] Astals, S., Batstone, D.J., Mata-Alvarez, J. and Jensen, P.D., 2014, Identification of synergistic impacts during anaerobic co-digestion of organic wastes. Bioresource Technology, 169, 421-427.

[3] Silvestre, G., Bonmatí, A. and Fernández, B., 2015, Optimisation of sewage sludge anaerobic digestion through co-digestion with OFMSW: Effect of collection system and particle size. Waste Management, 43, 137-143.

[4] Maragkaki, A.E., Fountoulakis, M., Gypakis, A., Kyriakou, A., Lasaridi, K. and Manios, T., 2016, Pilot-scale anaerobic co-digestion of sewage sludge with agro-industrial by-products for increased biogas production of existing digesters at wastewater treatment plants. Waste Management, 59, 362-370.

[5] Davidsson, A., Lövstedt, C., la Cour Jansen, J., Gruvberger, C. and Aspegren, H., 2008, Codigestion of grease trap sludge and sewage sludge. Waste Management, 28, 986-992.

[6] Palatsi, J., Viñas, M., Guivernau, M., Fernandez, B. and Flotats, X., 2011, Anaerobic digestion of slaughterhouse waste: Main process limitations and microbial community interactions. Bioresource Technology, 102, 2219-2227.

[7] Girotto, F., Alibardi, L. and Cossu, R., 2015, Food waste generation and industrial uses: A review. Waste Management, 45, 32-41.

[8] Xie, S., Wickham, R. and Nghiem, L.D., 2017, Synergistic effect from anaerobic co-digestion of sewage sludge and organic wastes. International Biodeterioration \& Biodegradation, 116, 191-197.

[9] Wang, B., Strömberg, S., Li, C., Nges, I.A., Nistor, M., Deng, L. and Liu, J., 2015, Effects of substrate concentration on methane potential and degradation kinetics in batch anaerobic digestion. Bioresource Technology, 194, 240-246.

[10] Zonta, Ž., Alves, M.M., Flotats, X. and Palatsi, J., 2013, Modelling inhibitory effects of long chain fatty acids in the anaerobic digestion process. Water Research, 47, 1369-1380. 
[11] Edwards, J., Othman, M., Crossin, E. and Burn, S., 2017, Anaerobic co-digestion of municipal food waste and sewage sludge: A comparative life cycle assessment in the context of a waste service provision. Bioresource Technology, 223, 237-249.

[12] Silvestre, G., Rodríguez-Abalde, A., Fernández, B., Flotats, X. and Bonmatí, A., 2011, Biomass adaptation over anaerobic co-digestion of sewage sludge and trapped grease waste. Bioresource Technology, 102, 6830-6836.

[13] Wang, B., Strömberg, S., Nges, I.A., Nistor, M. and Liu, J., 2016, Impacts of inoculum pretreatments on enzyme activity and biochemical methane potential. Journal of Bioscience and Bioengineering, 121, 557-560.

[14] Nghiem, L.D., Koch, K., Bolzonella, D. and Drewes, J.E., 2017, Full scale co-digestion of wastewater sludge and food waste: Bottlenecks and possibilities. Renewable and Sustainable Energy Reviews, 72, 354-362.

[15] Alanya, S., Yilmazel, Y.D., Park, C., Willis, J.L., Keaney, J., Kohl, P.M., Hunt, J.A. and Duran, M., 2013, Anaerobic co-digestion of sewage sludge and primary clarifier skimmings for increased biogas production. Water Science \& Technology, 67, 174-179.

[16] Edwards, J., Othman, M. and Burn, S., 2015, A review of policy drivers and barriers for the use of anaerobic digestion in Europe, the United States and Australia. Renewable and Sustainable Energy Reviews, 52, 815-828.

[17] Council Directive, 1999, Council Directive 1999/31/EC on the landfill. Official Journal of the European Communities, L182, 1-19.

[18] European Parliament, 2009, Directive 2009/28/EC of the European Parliament and of the Council of 23 April 2009. Official Journal of the European Union, 140, 16-62.

[19] SEAI (Sustainable Energy Authority or Ireland), 2016, Energy in Ireland 1990-2015. Report prepared by Martin Howley and Mary Holland, Energy Policy Statistical Support Unit. 88. Available online at: http://www.seai.ie/resources/publications/Energy-in-Ireland-1990-2015. pdf.

[20] DCENR (Department of Communications, Energy and Natural Resources), 2015, Consultation on amendments to the REFIT 3 terms and conditions, 13. Available online at: http://www.dccae. gov.ie/enie/energy/consultations/Documents/13/consultations/REFIT\%203\%20Terms\%20 and\%20conditions\%20consultation\%20-\%20July\%202015.pdf.

[21] DEFRA (Department for Environment, Food and Rural Affairs), 2009, The Environment in your pocket 2009, 104. Available online at: https://www.gov.uk/government/uploads/system/ uploads/attachment_data/file/69190/pb13319-eiyp2009-091119.pdf.

[22] DEFRA (Department for Environment, Food and Rural Affairs), 2011, Guidelines to Defra / DECC's GHG Conversion Factors for Company Reporting: Methodology Paper for Emission Factors, 102. Available online at: https://www.gov.uk/government/uploads/system/uploads/ attachment_data/file/69314/pb13625-emission-factor-methodology-paper-110905.pdf.

[23] Ponsá, S., Gea, T. and Sánchez, A., 2011, Anaerobic co-digestion of the organic fraction of municipal solid waste with several pure organic co-substrates. Biosystems Engineering, 108, 352-360.

[24] Esposito, G., Frunzo, L., Liotta, F., Panico, A. and Pirozzi, F., 2012, Bio-methane potential tests to measure the biogas production from the digestion and co-digestion of complex organic substrates. The Open Environmental Engineering Journal, 5, 1-8.

[25] Labatut, R.A., Angenent, L.T. and Scott, N.R., 2011, Biochemical methane potential and biodegradability of complex organic substrates. Bioresource Technology, 102, 2255-2264.

[26] Cavinato, C., Bolzonella, D., Pavan, P., Fatone, F. and Cecchi, F., 2013, Mesophilic and thermophilic anaerobic co-digestion of waste activated sludge and source sorted biowaste in pilot- and full-scale reactors. Renewable Energy, 55, 260-265.

[27] Lafitte-Trouqué, S. and Forster, C., 2000, Dual anaerobic co-digestion of sewage sludge and confectionery waste. Bioresource Technology, 71, 77-82.

[28] Stroot, P., 2001, Anaerobic codigestion of municipal solid waste and biosolids under various mixing conditions - I. digester performance. Water Research, 35, 1804-1816.

[29] Kim, J. and Kang, C.-M., 2015, Increased anaerobic production of methane by co-digestion of sludge with microalgal biomass and food waste leachate. Bioresource Technology, 189, 409-412. 
[30] Kim, H.-W., Nam, J.-Y. and Shin, H.-S., 2011, A comparison study on the high-rate co-digestion of sewage sludge and food waste using a temperature-phased anaerobic sequencing batch reactor system. Bioresource Technology, 102, 7272-7279.

[31] Giuliano, A., Bolzonella, D., Pavan, P., Cavinato, C. and Cecchi, F., 2013, Co-digestion of livestock effluents, energy crops and agro-waste : Feeding and process optimization in mesophilic and thermophilic conditions. Bioresource Technology, 128, 612-618.

[32] Koch, K., Plabst, M., Schmidt, A., Helmreich, B. and Drewes, J.E., 2016, Co-digestion of food waste in a municipal wastewater treatment plant: Comparison of batch tests and full-scale experiences. Waste Management, 47, 28-33.

[33] Tuyet, N.T., Dan, N.P., Vu, N.C., Trung, N.L.H., Thanh, B.X., De Wever, H., Goemans, M. and Diels, L., 2016, Laboratory-scale membrane up-concentration and co-anaerobic digestion for energy recovery from sewage and kitchen waste. Water Science and Technology, 73, 597-606.

[34] Liu, X., Gao, X., Wang, W., Zheng, L., Zhou, Y. and Sun, Y., 2012, Pilot-scale anaerobic codigestion of municipal biomass waste: Focusing on biogas production and GHG reduction. Renewable Energy, 44, 463-468.

[35] Murto, M., Björnsson, L. and Mattiasson, B., 2004, Impact of food industrial waste on anaerobic co-digestion of sewage sludge and pig manure. Journal of Environmental Management, 70, 101-107.

[36] Davidsson, A., Wawrzynczyk, J., Norrlow, O. and Jansen, J. La Cour, 2007, Strategies for enzyme dosing to enhance anaerobic digestion of sewage sludge. Journal of Residuals Science and Technology, 4, 1-7.

[37] Luste, S. and Luostarinen, S., 2010, Anaerobic co-digestion of meat-processing by-products and sewage sludge - Effect of hygienization and organic loading rate. Bioresource Technology, 101, 2657-2664.

[38] Long, J.H., Aziz, T.N., Reyes, F.L.D.L. and Ducoste, J.J., 2012, Anaerobic co-digestion of fat, oil, and grease (FOG): A review of gas production and process limitations. Process Safety and Environmental Protection, 90, 231-245.

[39] Martínez, E.J., Fierro, J., Sánchez, M.E. and Gómez, X., 2012, Anaerobic co-digestion of FOG and sewage sludge: Study of the process by Fourier transform infrared spectroscopy. International Biodeterioration \& Biodegradation, 75, 1-6.

[40] Nghiem, L.D., Nguyen, T.T., Manassa, P., Fitzgerald, S.K., Dawson, M. and Vierboom, S., 2014, Co-digestion of sewage sludge and crude glycerol for on-demand biogas production. International Biodeterioration and Biodegradation, 95, 160-166.

[41] Wang, B., Nges, I.A., Nistor, M. and Liu, J., 2014, Determination of methane yield of cellulose using different experimental setups. Water Science and Technology, 70, 599-604.

[42] Einola, J.K., Luostarinen, S.A., Salminen, E.A. and Rintala, J., 2001, Screening for an optimal combination of municipal and industrial wastes and sludges for anaerobic co-digestion. In: Proceedings of the 9th World Congress, Anaerobic Digestion 2001, Antwerpen, Belgium, pp. 357-362.

[43] Shin, S. G., Zhou, B. W., Lee, S., Kim, W. and Hwang, S., 2011, Variations in methanogenic population structure under overloading of pre-acidified high-strength organic wastewaters. Process Biochemistry, 46, 1035-1038.

[44] Sun, Y., Wang, D., Yan, J., Qiao, W., Wang, W. and Zhu, T., 2014, Effects of lipid concentration on anaerobic co-digestion of municipal biomass wastes. Waste Management, 34, 1025-1034.

[45] Fonoll, X., Astals, S., Dosta, J. and Mata-Alvarez, J., 2015, Anaerobic co-digestion of sewage sludge and fruit wastes: Evaluation of the transitory states when the co-substrate is changed. Chemical Engineering Journal, 262, 1268-1274.

[46] Committe on World Food Security, 2014, Food Losses and Waste in the Context of Sustainable Food Systems. A Report by the High Level Panel of Experts on Food Security and Nutrition of the Committee on World Food Security (Rome: UN Committee on World Food Security (CFS)).

[47] Gustavsson, J., Cederberg, C., Sonesson, U., Van Otterdijk, R. and Meybeck, A., 2011, Global Food Losses and Food Waste - Extent, Causes and Prevention (Rome: Food and Agriculture Organization of the United Nations (FAO)). 
[48] EPA, E. P. A., 2014, Licensed Sites 2014 Report on Air Emissions (Dublin, Ireland: Environmental Protection Agency).

[49] Lee, D.J., Lee, S.Y., Bae, J.S., Kang, J.G., Kim, K.H., Rhee, S.S., Park, J.H., Cho, J.S., Chung, J. and Seo, D.C., 2015, Effect of volatile fatty acid concentration on anaerobic degradation rate from field anaerobic digestion facilities treating food waste leachate in South Korea. Journal of Chemistry, 2015, 9.

[50] Liu, X., Wang, W., Shi, Y., Zheng, L., Gao, X., Qiao, W. and Zhou, Y., 2012, Pilot-scale anaerobic co-digestion of municipal biomass waste and waste activated sludge in China: Effect of organic loading rate. Waste Management, 32, 2056-2060.

[51] He, X., de los Reyes, F.L., Leming, M.L., Dean, L.O., Lappi, S.E., and Ducoste, J.J., 2013, Mechanisms of fat, oil and grease (FOG) deposit formation in sewer lines. Water Research, 47, 4451-4459.

[52] Curran, T.P., 2015, Sustainable management of fat, oil and grease (FOG) waste - A global challenge. Sustainability Ireland, 8, 7-15.

[53] He, X., Osborne, J. and de los Reyes, F. L., 2012, Physico-chemical characterization of grease interceptors with and without biological product addition. Water Environment Research, 84, 195-201.

[54] Luostarinen, S., Luste, S. and Sillanpää, M., 2009, Increased biogas production at wastewater treatment plants through co-digestion of sewage sludge with grease trap sludge from a meat processing plant. Bioresource Technology, 100, 79-85.

[55] Long, J.H., Aziz, T.N., de los Reyes, F.L. and Ducoste, J.J., 2012, Anaerobic co-digestion of fat, oil, and grease (FOG): A review of gas production and process limitations. Process Safety and Environmental Protection, 90, 231-245.

[56] Maragkaki, A.E., Vasileiadis, I., Fountoulakis, M., Kyriakou, A., Lasaridi, K. and Manios, T., 2017, Improving biogas production from anaerobic co-digestion of sewage sludge with a thermal dried mixture of food waste, cheese whey and olive mill wastewater. Waste Management in press.

[57] Palatsi, J., Laureni, M., Andrés, M.V., Flotats, X., Nielsen, H.B. and Angelidaki, I., 2009, Strategies for recovering inhibition caused by long chain fatty acids on anaerobic thermophilic biogas reactors. Bioresource Technology, 100, 4588-4596.

[58] Wang, L., Aziz, T.N. and de los Reyes, F. L., 2013, Determining the limits of anaerobic codigestion of thickened waste activated sludge with grease interceptor waste. Water Research, 47, 3835-3844.

[59] Cho, H.S., Moon, H.S., Lim, J.Y. and Kim, J.Y., 2013, Effect of long chain fatty acids removal as a pretreatment on the anaerobic digestion of food waste. Journal of Material Cycles and Waste Management, 15, 82-89.

[60] Wang, J., Zhang, Y., Han, L., Chang, L. and Bao, W., 2013, Simultaneous removal of hydrogen sulfide and mercury from simulated syngas by iron-based sorbents. Fuel, 103, 73-79.

[61] Girault, R., Bridoux, G., Nauleau, F., Poullain, C., Buffet, J., Peu, P., Sadowski, A.G. and Béline, F., 2012, Anaerobic co-digestion of waste activated sludge and greasy sludge from flotation process: Batch versus CSTR experiments to investigate optimal design. Bioresource Technology, $105,1-8$.

[62] Razaviarani, V., Buchanan, I.D., Malik, S. and Katalambula, H., 2013, Pilot-scale anaerobic co-digestion of municipal wastewater sludge with restaurant grease trap waste. Journal of Environmental Management, 123, 26-33.

[63] Borowski, S. and Kubacki, P., 2015, Co-digestion of pig slaughterhouse waste with sewage sludge. Waste Management, 40, 119-126.

[64] Neczaj, E., Bien, J., Grosser, A., Worwag, M. and Kacprzak, M., 2012, Anaerobic treatment of sewage sludge and grease trap sludge in continuous co-digestion. Global Nest Journal, 14, 141-148.

[65] Iacovidou, E., Ohandja, D.-G., Gronow, J. and Voulvoulis, N., 2012, The household use of food waste disposal units as a waste management option: A review. Critical Reviews in Environmental Science and Technology, 42, 1485-1508. 
[66] Suto, P., Gray, D. M. D., Larsen, E., and Hake, J., 2006, Innovative anaerobic digestion investigation of fats, oils, and grease. Proceedings of the Water Environment Federation, Residuals and Biosolids Management, 22, 858-879.

[67] Appels, L., Lauwers, J., Degrève, J., Helsen, L., Lievens, B., Willems, K., Van Impe, J. and Dewil, R., 2011, Anaerobic digestion in global bio-energy production: Potential and research challenges. Renewable and Sustainable Energy Reviews, 15, 4295-4301.

[68] Sun, Y., Wang, D., Yan, J., Qiao, W., Wang, W. and Zhu, T., 2014, Effects of lipid concentration on anaerobic co-digestion of municipal biomass wastes. Waste Management, 34, 1025-1034.

[69] Wu, S., Ni, P., Li, J., Sun, H., Wang, Y., Luo, H., Dach, J. and Dong, R., 2016, Integrated approach to sustain biogas production in anaerobic digestion of chicken manure under recycled utilization of liquid digestate: Dynamics of ammonium accumulation and mitigation control. Bioresource Technology, 205, 75-81.

[70] Kim, M., Morrison, M., and Yu, Z., 2011, Status of the phylogenetic diversity census of ruminal microbiomes, FEMS Microbiology Ecology, 76, 49-63.

[71] Krupp, M., Schubert, J. and Widmann, R., 2005, Feasibility study for co-digestion of sewage sludge with OFMSW on two wastewater treatment plants in Germany. Waste Management, 25, 393-399.

[72] Mottet, A., Steyer, J.P., Déléris, S., Vedrenne, F., Chauzy, J. and Carrère, H., 2010, Estimating anaerobic biodegradability indicators for waste activated sludge. Chemical Engineering Journal, 160, 488-496.

[73] Kim, H.-W., Han, S.-K. and Shin, H.-S., 2003, The optimisation of food waste addition as a cosubstrate in anaerobic digestion of sewage sludge. Waste Management \& Research, 21, 515-526.

[74] Heo, N.H., Park, S.C., Lee, J.S., Kang, H. and Park, D.H., 2003, Single-stage anaerobic codigestion for mixture wastes of simulated korean food waste and waste activated sludge. In: B.H. Davison, J.W. Lee, M. Finkelstein and J.D. McMillan (Eds) Biotechnology for Fuels and Chemicals: The Twenty-fourth Symposium (Totowa, NJ: Humana Press), pp. 567-579.

[75] Sosnowski, P., Wieczorek, A. and Ledakowicz, S., 2003, Anaerobic co-digestion of sewage sludge and organic fraction of municipal solid wastes. Advances in Environmental Research, 7, 609-616.

[76] Zhang, P., Zeng, G., Zhang, G., Li, Y., Zhang, B. and Fan, M., 2008, Anaerobic co-digestion of biosolids and organic fraction of municipal solid waste by sequencing batch process. Fuel Processing Technology, 89, 485-489.

[77] Wang, H., Fotidis, I. A., and Angelidaki, I., 2015, Ammonia effect on hydrogenotrophic methanogens and syntrophic acetate-oxidizing bacteria, FEMS Microbiology Ecology, 91, $130-138$.

[78] Zhang, C., Su, H. and Tan, T., 2013, Batch and semi-continuous anaerobic digestion of food waste in a dual solid-liquid system. Bioresource Technology, 145, 10-16.

[79] Angelidaki, I. and Sanders, W., 2004, Assessment of the anaerobic biodegradability of macropollutants. Reviews in Environmental Science and Bio/Technology, 3, 117-129.

[80] Iacovidou, E., Ohandja, D.-G. and Voulvoulis, N., 2012, Food waste co-digestion with sewage sludge - Realising its potential in the UK. Journal of Environmental Management, 112, 267-274.

[81] Angelidaki, I., Alves, M., Bolzonella, D., Borzacconi, L., Campos, J.L., Guwy, A.J., Kalyuzhnyi, S., Jenicek, P. and van Lier, J.B., 2009, Defining the biomethane potential (BMP) of solid organic wastes and energy crops: A proposed protocol for batch assays. Water Science and Technology, 59, 927-934.

[82] Kafle, G.K., Kim, S.H. and Shin, B.S., 2012, Anaerobic digestion treatment for the mixture of Chinese cabbage waste juice and swine manure. Journal of Biosystems Engineering, 37, 58-64.

[83] Banks, C.J., Chesshire, M., Heaven, S. and Arnold, R., 2011, Anaerobic digestion of sourcesegregated domestic food waste: Performance assessment by mass and energy balance. Bioresource Technology, 102, 612-620.

[84] Mata-Alvarez, J., Dosta, J., Romero-Güiza, M.S., Fonoll, X., Peces, M. and Astals, S., 2014, A critical review on anaerobic co-digestion achievements between 2010 and 2013. Renewable and Sustainable Energy Reviews, 36, 412-427. 
[85] Climenhaga, M.A. and Banks, C.J., 2009, Anaerobic digestion of catering wastes: Effect of micronutrients and retention time. Water Science \& Technology, 57, 687-692.

[86] Zhang, C., Xiao, G., Peng, L., Su, H. and Tan, T., 2013, The anaerobic co-digestion of food waste and cattle manure. Bioresource Technology, 129, 170-176.

[87] Chen, Xiguang, Romano, Rowena T. and Zhang, R., 2010, Anaerobic digestion of food wastes for biogas production. International Journal of Agricultural and Biological Engineering, 3, 61-72.

[88] de Baere, L. and Mattheeuws, B., 2010, Anaerobic digestion of MSW in Europe. BioCycle, 51, $24-26$.

[89] Noutsopoulos, C., Mamais, D., Antoniou, K., Avramides, C., Oikonomopoulos, P. and Fountoulakis, I., 2013, Anaerobic co-digestion of grease sludge and sewage sludge: The effect of organic loading and grease sludge content. Bioresource Technology, 131, 452-459.

[90] Buendía, I.M., Fernández, F.J., Villaseñor, J. and Rodríguez, L., 2009, Feasibility of anaerobic co-digestion as a treatment option of meat industry wastes. Bioresource Technology, 100, 1903-1909.

[91] Pitk, P., Kaparaju, P., Palatsi, J., Affes, R. and Vilu, R., 2013, Co-digestion of sewage sludge and sterilized solid slaughterhouse waste: Methane production efficiency and process limitations. Bioresource Technology, 134, 227-232.

[92] Kabouris, J.C., Tezel, U., Pavlostathis, S.G., Engelmann, M., Dulaney, J., Gillette, R.A. and Todd, A.C., 2009, Methane recovery from the anaerobic codigestion of municipal sludge and FOG. Bioresource Technology, 100, 3701-3705.

[93] Carrere, H., Rafrafi, Y., Battimelli, A., Torrijos, M., Delgenes, J.P. and Motte, C., 2012, Improving methane production during the codigestion of waste-activated sludge and fatty wastewater: Impact of thermo-alkaline pretreatment on batch and semi-continuous processes. Chemical Engineering Journal, 210, 404-409.

[94] Pastor, L., Ruiz, L., Pascual, A. and Ruiz, B., 2013, Co-digestion of used oils and urban landfill leachates with sewage sludge and the effect on the biogas production. Applied Energy, 107, 438-445.

[95] Wan, C., Zhou, Q., Fu, G. and Li, Y., 2011, Semi-continuous anaerobic co-digestion of thickened waste activated sludge and fat, oil and grease. Waste Management, 31, 1752-1758.

[96] Hosseini Koupaie, E., Barrantes Leiva, M., Eskicioglu, C. and Dutil, C., 2014, Mesophilic batch anaerobic co-digestion of fruit-juice industrial waste and municipal waste sludge: Process and cost-benefit analysis. Bioresource Technology, 152, 66-73.

[97] Cirne, D.G., Paloumet, X., Björnsson, L., Alves, M.M. and Mattiasson, B., 2007, Anaerobic digestion of lipid-rich waste - Effects of lipid concentration. Renewable Energy, 32, 965-975.

[98] Pagés-Díaz, J., Pereda-Reyes, I., Taherzadeh, M. J., Sárvári-Horváth, I., and Lundin, M., 2014, Anaerobic co-digestion of solid slaughterhouse wastes with agro-residues: Synergistic and antagonistic interactions determined in batch digestion assays, Chemical Engineering Journal, 245, 89-98.

[99] Pahl, O., Firth, A., MacLeod, I. and Baird, J., 2008, Anaerobic co-digestion of mechanically biologically treated municipal waste with primary sewage sludge - A feasibility study. Bioresource Technology, 99, 3354-3364.

[100] Sosnowski, P., Klepacz-Smolka, A., Kaczorek, K. and Ledakowicz, S., 2008, Kinetic investigations of methane co-fermentation of sewage sludge and organic fraction of municipal solid wastes. Bioresource Technology, 99, 5731-5737.

[101] Zhang, T., Mao, C., Zhai, N., Wang, X. and Yang, G., 2015, Influence of initial pH on thermophilic anaerobic co-digestion of swine manure and maize stalk. Waste Management, 35, 119-126.

[102] Zhang, W., Lang, Q., Fang, M., Li, X., Bah, H., Dong, H. and Dong, R., 2017, Bioresource Technology Combined effect of crude fat content and initial substrate concentration on batch anaerobic digestion characteristics of food waste. Bioresource Technology, 232, 304-312.

[103] Chen, Y., Cheng, J.J. and Creamer, K.S., 2008, Inhibition of anaerobic digestion process: A review. Bioresource Technology, 99, 4044-4064.

[104] Ziels, R.M., Karlsson, A., Beck, D.A.C., Ejlertsson, J., Yekta, S.S., Bjorn, A., Stensel, H.D. and Svensson, B.H., 2016, Microbial community adaptation influences long-chain fatty acid 
conversion during anaerobic codigestion of fats, oils, and grease with municipal sludge. Water Research, 103, 372-382.

[105] Appels, L., Baeyens, J., Degrève, J. and Dewil, R., 2008, Principles and potential of the anaerobic digestion of waste-activated sludge. Progress in Energy and Combustion Science, 34, 755-781.

[106] Yenigün, O. and Demirel, B., 2013, Ammonia inhibition in anaerobic digestion: A review. Process Biochemistry, 48, 901-911.

[107] Fotidis, I.A., Karakashev, D., Kotsopoulos, T.A., Martzopoulos, G.G., and Angelidaki, I., 2013, Effect of ammonium and acetate on methanogenic pathway and methanogenic community composition. FEMS Microbiology Ecology, 83, 38-48.

[108] Arhoun, B., Bakkali, A., El Mail, R., Rodriguez-Maroto, J.M. and Garcia-Herruzo, F., 2013, Biogas production from pear residues using sludge from a wastewater treatment plant digester. Influence of the feed delivery procedure. Bioresource Technology, 127, 242-247.

[109] Van Foreest, F. 2012, Perspectives for biogas in Europe (Oxford: Oxford Institute for Energy Studies).

[110] Ireland, 2011, European Communities (Waste Directive) Regulations 2011. Statutory Instruments No. 126, 2011.

[111] European Parliament and Council, 2008, Directive 2008/98/EC of the European Parliament and of the Council of 19 November 2008 on waste and repealing certain directives. Official Journal of the European Union, 3-30.

[112] Department of Agriculture Food and Marine (DAFM), 2014, European Union (Animal ByProducts) Regulations 2014. Statutory Instruments No 187.

[113] Adam, G., Lemaigre, S., Goux, X., Delfosse, P., and Romain, A.C., 2015, Upscaling of an electronic nose for completely stirred tank reactor stability monitoring from pilot-scale to real-scale agricultural co-digestion biogas plant. Bioresour Technol, 178, 285-296.

[114] Ganidi, N., Tyrrel, S. and Cartmell, E., 2009, Anaerobic digestion foaming causes - A review. Bioresource Technology, 100, 5546-5554.

[115] EPA, 2013, Environmental Protection Agency (Integrated Pollution Control) (Licensing) Regulations 2013. Statutory Instruments No 283.

[116] Ohandja, D. G., Gove, L., Edwards, M., Callan, J., and Voulvoulis, N., 2010, Improving anaerobic digester performance: lessons learnt from digester clean-out operations, Water Practice \& Technology, 5, 44.

[117] CIWEM, 2011, Co-digestion of sewage sludge and waste, 1043409.

[118] Celtic Anglian Water, 2016, Ringsend Wastewater Treatment Works, 2016. [Online]. Available: https://www.caw.ie/case-studies/ringsend-wastewater-treatment-works.

[119] Awe, O.W., Liu, R. and Zhao, Y., 2016, Analysis of energy consumption and saving in wastewater treatment plant : Case study from Ireland. Journal of Water Sustainability, 6, 63-76.

[120] Fisgativa, H., Tremier, A. and Dabert, P., 2016, Characterizing the variability of food waste quality: A need for efficient valorisation through anaerobic digestion. Waste Management, 50, 264-274.

[121] Alibardi, L. and Cossu, R., 2016, Effects of carbohydrate, protein and lipid content of organic waste on hydrogen production and fermentation products. Waste Management, 47, 69-77.

[122] Alibardi, L. and Cossu, R., 2015, Composition variability of the organic fraction of municipal solid waste and effects on hydrogen and methane production potentials. Waste Management, 36, 147-155.

[123] Edjabou, M.E., Jensen, M.B., Götze, R., Pivnenko, K., Petersen, C., Scheutz, C. and Astrup, T.F., 2015, Municipal solid waste composition: Sampling methodology, statistical analyses, and case study evaluation. Waste Management, 36, 12-23.

[124] Yan, Z., Song, Z., Li, D., Yuan, Y., Liu, X. and Zheng, T., 2015, The effects of initial substrate concentration, $\mathrm{C} / \mathrm{N}$ ratio, and temperature on solid-state anaerobic digestion from composting rice straw. Bioresource Technology, 177, 266-273.

[125] Belitz, H.D., Grosch, W. and Schieberle, P., 2009, Food Chemistry, 4th revised and extended edition (Berlin Heidelberg: Springer-Verlag), p. 114. 
[126] Carucci, G., Carrasco, F., Trifoni, K., Majone, M. and Beccari, M., 2005, Anaerobic digestion of food industry wastes: Effect of codigestion on methane yield. Journal of Environmental Engineering, 131, 1037-1045.

[127] Straka, F., Jenicek, P., Zabranska, J., Dohanyos, M. and Kuncarova, M., 2007, Anaerobic fermentation of biomass and wastes with respect to sulfur and nitrogen contents in treated materials. Sardinia Eleventh International Waste Management and Landfill Symposium, 33, $113-117$

[128] Lu, J., Gavala, H.N., Skiadas, I.V., Mladenovska, Z. and Ahring, B.K., 2008, Improving anaerobic sewage sludge digestion by implementation of a hyper-thermophilic prehydrolysis step. Journal of Environmental Management, 88, 881-889.

[129] Christ, O., Wilderer, P.A., Angerhöfer, R. and Faulstich, M., 2000, Mathematical modeling of the hydrolysis of anaerobic processes. Water Science and Technology: A Journal of the International Association on Water Pollution Research, 41, 61-65.

[130] Razaviarani, V. and Buchanan, I.D., 2014, Reactor performance and microbial community dynamics during anaerobic co-digestion of municipal wastewater sludge with restaurant grease waste at steady state and overloading stages. Bioresource Technology, 172, 232-240.

[131] Kim, H.-W., Nam, J.-Y. and Shin, H.-S., 2011, A comparison study on the high-rate co-digestion of sewage sludge and food waste using a temperature-phased anaerobic sequencing batch reactor system. Bioresource Technology, 102, 7272-7279.

[132] Dai, X., Duan, N., Dong, B. and Dai, L., 2013, High-solids anaerobic co-digestion of sewage sludge and food waste in comparison with mono digestions: Stability and performance. Waste Management, 33, 308-316.

[133] Jansen, J. la C., Gruvberger, C., Hanner, N., Aspegren, H. and Svärd, Á., 2004, Digestion of sludge and organic waste in the sustainability concept for Malmö, Sweden. Water Science and Technology, 49, 163-169.

[134] Heo, N.H., Park, S.C. and Kang, P.H., 2004, Effects of mixture ratio and hydraulic retention time on single-stage anaerobic co-digestion of food waste and waste activated sludge. Journal of Environmental Science and Health, Part A, 39, 1739-1756. 